\title{
REVISTAMARACANAN
}

Dossiê

\section{Iconografia da Intolerância: impressos no combate à idolatria em regiões sob colonização hispânica (séculos XVI- XVII)}

Jorge Victor de Araújo Souza *

Universidade Federal do Rio de Janeiro

Rio de Janeiro, Rio de Janeiro, Brasil

Natalia de Souza Miranda**

Universidade Federal do Rio de Janeiro

Rio de Janeiro, Rio de Janeiro, Brasil

Recebido em: 30 abr. 2021.

Aprovado em: 15 out. 2021.

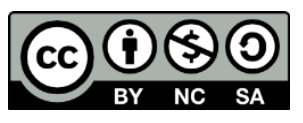

* Professor de História da América Colonial na Universidade Federal do Rio de Janeiro. Doutor em História pela Universidade Federal Fluminense. Mestre em História Social pela Universidade Federal do Rio de Janeiro. (jvictoraraujos@gmail.com).

(iD) https://orcid.org/0000-0002-5026-7120

(9) http://lattes.cnpq.br/4254754350213135

** Mestranda pelo Programa de Pós-Graduação em História Comparada da UFRJ. Graduada e Licenciada em História pela Universidade Federal do Rio de Janeiro. (mirandas.natalia@gmail.com)

(iD) https://orcid.org/0000-0002-6472-0117

(9) http://lattes.cnpq.br/0256370797361552 


\title{
Resumo
}

Este artigo defende a ideia de que houve certa reinvenção da idolatria por parte de impressos publicados entre os séculos XVI e XVII, sobretudo os que possuíam gravuras que representavam os atos de violência contra os ameríndios. Para isso, tem como base a análise de algumas imagens do acervo da John Carter Brown Library sobre a colonização da América hispânica, onde se reúne preciosa coleção de impressos e gravuras. No entanto, vai-se além desse corpus documental. O artigo objetiva destacar a importância dos conceitos de "idolatria" e "idoloclastia" para a compreensão das colonizações ibéricas, bem como demonstrar a relação entre a performance da destruição de ídolos presente nas imagens e a ideia de exorcismo da paisagem colonial, importante no domínio dos territórios conquistados.

Palavras-chave: Cultura visual. Ídolo. Idolatria. Idoloclastia. Conquista. Colonização.

\begin{abstract}
This article defends the idea that there was a reinvention of idolatry on part of printed matter published between the 16th and 17th centuries, mainly due to the presence of engravings. In this respect, it is based on the analysis of the John Carter Brown Library on the colonization of hispanic America, where there are gathered a precious collection of prints and engravings. However, it goes beyond this documental corpus. Its aim is to highlight the relevance of concepts such as "idolatry" and "idoloclasm", for the understanding of Iberian colonizations as well as to demonstrate the relationship between the destruction of idols present in the images and the idea of an exorcism of the colonial landscape, fundamental for the dominion of the conquered territories.
\end{abstract}

Keywords: Visual culture. Idol. Idolatry. Idoloclast. Conquest. Colonization. 
Se a forma mais dramática do poder da imagem na cultura visual é a idolatria, ela também é uma força consideravelmente ambivalente e ambígua. ${ }^{1}$

\section{Introdução}

Cotejando e atentando a detalhes gestuais presentes em estampas avulsas e gravadas em livros, mostraremos o quanto o conceito de "idolatria" e, por conseguinte, o de "idoloclastia", são centrais para a compreensão da conquista e da colonização de matriz hispânica. Portanto, analisar aspectos entre a relação da cultura visual e da cultura escrita no primeiro século da colonização se faz mister à historiografia sobre o tema, assim como investigar a historicidade dos referidos conceitos. Nesse sentido, seguimos os passos de Luciana Villas Bôas que, em recente publicação, preocupada com a semântica do descobrimento, salientou que: "os primeiros relatos do Novo Mundo eram uma oportunidade para a definição da identidade dos sujeitos europeus". A autora afirma que o livro impresso foi um dos palcos para a disputa europeia pelo Novo Mundo. ${ }^{2}$ Por meio dos impressos, é possível reconhecer diversas estratégias legitimadoras da posse das terras recém-descobertas. Nossa hipótese é a de que, independente da forma como o corpo do ídolo ameríndio tenha sido representado nos impressos entre os séculos XVI e XVII - como demônio de variada tipologia e diversos suportes, ou até como o próprio corpo indígena -, a performance de sua destruição assemelhava-se a um exorcismo do território conquistado, criando uma paisagem colonial cristianizada.

Para tal, fizemos uso dos relatos de cronistas coloniais e de publicações impressas, como documentação escrita, e circunscrevemos o início de nossa pesquisa ao corpus imagético da John Carter Brown Library, uma das mais completas bases de dados imagéticos digitalizados para estudos da Época Moderna, mormente aos que concernem à colonização das Américas. Selecionamos para a pesquisa as gravuras e demais documentos em que se notam gestos de destruição dos denominados ídolos nativos. Cabe salientar que, acompanhando as diretrizes metodológicas de Aby Warburg, produzimos uma "montagem" de imagens, selecionadas a partir

1 MITCHELL, W.J.T. O que as imagens querem? In: ALLOA, Emmanuel (Org.). Pensar a imagem. Belo Horizonte: Autêntica, 2015. p. 172.

2 VILLAS BÔAS, Luciana. Encontros escritos: semântica histórica do Brasil no século XVI. Rio de Janeiro: Editora da UFRJ, 2019, p. 20. 
do que aqui chamamos pathosphormel da idoloclastia. ${ }^{3} \mathrm{Em}$ Warburg, esse procedimento teóricometodológico é definido pelo filósofo francês Georges Didi-Huberman, desta forma:

A montagem - pelo menos no sentido que nos interessa aqui - não é a criação artificial de uma continuidade temporal a partir de "planos" descontínuos, dispostos em sequências. Ao contrário, é um modo de expor visualmente as descontinuidades do tempo que atuam em todas as sequências da história. ${ }^{4}$

Ainda quanto ao aspecto metodológico, ressaltamos que a pesquisa de imagens, ao modo de Warburg, não respeita fronteiras geográficas, tampouco temporais, ou melhor dizendo, as imagens não respeitam tais restrições. O próprio suporte - o livro - circulava com certa facilidade no período aqui estudado - edições ilustradas de Ovídio chegavam à Lima, por exemplo -, e as gravuras avulsas podiam ser dobradas e colocadas em um bolso. Na própria produção das imagens, notamos a capacidade de circulação e trocas envolvidas. Uma gravura feita por um artista espanhol para ser publicada em Portugal, como ilustração da obra de um pensador alemão, poderia ter como modelo a iconografia de um herói da Antiguidade Clássica. Embora tenhamos delimitado o início da pesquisa partindo de imagens do Novo Mundo, foi preciso ampliar as fronteiras da investigação para acompanharmos imagens que foram compartilhadas em diversos espaços sob colonização europeia, e que possuíam uma longa tradição iconográfica.

Em pleno período conhecido como Renascimento, foram cunhadas imagens que tentavam representar as vastas áreas na Ásia, África e América, que então estavam sob algum tipo de domínio imperial de governos europeus. Foram imagens criadas, sobretudo, por um "olhar colonizador". Olhar que buscou normatizar certa subalternização dos povos não europeus, que mirou as riquezas naturais das regiões colonizadas, e que criou narrativas para justificar a imposição de todos os meios de violência contra os povos nativos, subjugando-os. Enfim, neste período consolidou-se um olhar preocupado, sobretudo, em explorar terras e gentes. ${ }^{5}$

Usando o conceito nativo de "pessoa distribuída", cunhado por Alfred Gell, abordamos esses ídolos como objetos "relativos à pessoa", "alvos de agência social". De acordo com o antropólogo, pensando o contexto da idolatria: "o ídolo não é o retrato do Deus, mas o corpo do

\footnotetext{
3 Aby Warburg analisou a produção artística do primeiro período do Renascimento, observando nas iconografias e na poesia o que ele denominou "fórmula de páthos", isto é, a representação de diversos atributos, gestos e expressões em que estão subsumidos valores, emoções, ideias. Segundo Warburg, tal pathosphormel possui raízes na Antiguidade Clássica, atravessando diversos séculos, numa verdadeira "sobrevivência" imagética. Neste artigo, defendemos a ideia de que existe, nas imagens e nos textos analisados, uma fórmula típica da destruição de ídolos. Cf: WARBURG, Aby. Dürer e a Antiguidade italiana. In. Histórias de fantasma para gente grande. Escritos, esboços e conferências. São Paulo: Companhia das Letras, 2015, pp. 69-80.

${ }^{4}$ DIDI-HUBERMAN, Georges. A imagem sobrevivente. História da arte e tempo dos fantasmas segundo Aby Warburg. Rio de Janeiro: Contraponto, 2013, p. 400.

$5 \mathrm{Em}$ que pese os autores não usarem a expressão "olhar colonizador", pode-se concluir a existência deste olhar por conta de certa "cultura visual colonizadora" abordada em suas obras, Cf.: GERBI, Antonello. O Novo Mundo. História de uma polêmica (1750-1900). São Paulo: Companhia das Letras, 1996; GREENBLATT, Stephen. Possessões maravilhosas. O deslumbramento do Novo Mundo. São Paulo: EDUSP, 1996. PRATT, Mary Louise. Os olhos do Império. Relatos de viagem e transculturação. São Paulo: EDUSC, 1999.
} 
Deus em forma-artefato". ${ }^{6}$ Podemos questionar o limite do conceito de "pessoa distribuída", já que aqui ele não se aplica diretamente aos objetos materiais, em geral confeccionados em pedra, que os nativos mantinham em frente aos olhos em suas práticas religiosas. Entretanto, somos levados a crer que os europeus, sobretudo em gravuras que envolviam ritos de violência, com a destruição dos ídolos, se representaram visualmente como se estivessem agindo contra pessoas de carne e osso, exorcizando a paisagem colonial. No contexto da cultura católica, as atuações dos destruidores de ídolos aproximavam-se do que ocorre durante os rituais da conhecida ação popular denominada "malhação de Judas".

A colonização das Américas foi uma ação de amplitude global no começo da modernidade. Explica-se: nem todas as monarquias e repúblicas europeias possuíam domínios em outras partes do mundo, o que não quer dizer que não tenham usufruído, em alguma medida, da circulação de riquezas empreendida pela exploração das áreas colonizadas e pelo uso das mãos de obra escravizada indígena e negra africana. ${ }^{7}$ Neste artigo, analisamos certas estratégias visuais presentes nos impressos, no intuito de melhor entendermos como se formaram verdadeiras "paisagens coloniais" que corroboravam com expectativas mercantis, políticas e culturais dos europeus. Tais imagens representaram ambições metropolitanas, e fizeram parte da cultura visual da Época Moderna. ${ }^{8}$

Para o campo de estudos denominado "Cultura visual", W.J.T. Mitchell, historiador da arte, é referência incontornável, sobretudo por conta de seu artigo The pictorial turn, onde definiu os principais termos de análise de imagem para além do estudo iconográfico realizado por Erwin Panofsky. ${ }^{9}$ Em outro artigo, que se tornou referência para o campo, Mitchell se pergunta "o que as imagens realmente querem?". Para ele, as imagens são imbuídas de um agenciamento, o que as torna ambíguas: possuem poder, mas são frágeis na mesma medida. Essa ambiguidade está presente, segundo ele, nas passagens bíblicas que condenam a idolatria, pois, para tal, são usados os termos "abominação" e "adoração". ${ }^{10}$ Como mostraremos, é possível notar tal ambiguidade nas representações desta antiga prática condenatória aos chamados idólatras.

Quais são as relações entre cultura visual e cultura escrita na Época Moderna? Dentre os possíveis vínculos destas culturas, a que aqui nos interessa é a que tange o uso de imagens em livros e estampas avulsas. Para Elisabeth Eisenstein, tratando da "revolução impressa": "o fato de que imagens, mapas e diagramas idênticos podiam ser vistos simultaneamente por muitos leitores esparsos constitui por si só uma espécie de revolução". A historiadora ressalta uma

6 GELL, Alfred. Arte e agência. Uma teoria antropológica. São Paulo: Ubu Editora, 2018, p. 159.

7 WOLF, Eric R. A Europa e os povos sem história. São Paulo: EDUSP, 2005.

8 Para uma apreciação aprofundada, e um balanço bibliográfico a respeito da noção de "Cultura Visual" e da sua relação com os estudos históricos, Cf.: KNAUSS, Paulo. Aproximações disciplinares: História, Arte e Imagem. Anos 90, Porto Alegre, v. 15, n. 28, p.151-168, dez. 2008.

9 Cf. MITCHELL, W.T.J. Picture Theory. Chicago: Chicago Press, 1994.

10 MITCHELL, O que as imagens querem?, Op. cit., p. 165-189. 
característica crucial ao destacar a potência de vulgarização de imagens e ideias que se alcançou com a imprensa. ${ }^{11}$ Especificamente para o espaço ibérico, os estudos do historiador Fernando Bouza destacaram a relação entre gravuras e cultura escrita na definição de uma cultura política dos séculos XVI e XVII. Nestes textos, Bouza chama a atenção para o papel propagandístico de tais publicações, incluindo a construção da imagem do rei Felipe II. ${ }^{12}$

Podemos, agora, questionar em que medida este amálgama entre o visível e o dizível, entre as gravuras e as letras, contribuiu para a reinvenção de uma prática bastante antiga - a idolatria -, assim como os discursos que buscavam extirpá-la.

Há trinta anos, Serge Gruzinski lançava seu livro mais conhecido: A Guerra das Imagens: De Cristóvão Colombo a Blade Runner (1492-2019). Nele, o historiador francês discorre sobre uma hipótese bastante original para a época: a de que as imagens europeias - sobretudo religiosas - tiveram papel crucial na conquista das Américas. Houve uma "guerra" assimétrica, pois do lado nativo não houve todo o projeto do uso das imagens para a conquista do imaginário espanhol. Concordamos com Gruzinski quando afirma que muitas imagens serviram para os nativos como importantes lugares de memória, auxiliando na preservação dos cultos, cerimônias, identidades e deuses dos povos ancestrais. Por esse mesmo motivo, uma quantidade extraordinária de imagens produzidas por nativos foi sistematicamente destruída pelos conquistadores europeus de corpos e almas. Gruzinski fala em uma "idoloclastia" ao enquadrar tal situação colonial. Para os conquistadores/colonizadores que avançavam sobre as terras indígenas, a "idolatria fornece tanto argumento como álibi", afirma o historiador. ${ }^{13}$ Buscamos complementar as análises de Gruzinski, ao analisarmos uma perspectiva que teve pouca atenção em suas obras: as imagens das performances da sistemática destruição dos ídolos.

Em 1969, o historiador da arte David Freedberg inovou em sua área de conhecimento ao propor uma tese sobre a destruição de imagens ocorrida nos Países Baixos no ano de 1566, no contexto das guerras religiosas. Para Freedberg, a principal questão era de ordem teológica - a questão da encarnação do invisível - mas, não deixou de ser também uma questão política, na medida em que os partidários - católicos e protestantes - vivenciavam uma cultura política regida pelo lema cujus regio, eius religio; grosso modo: os súditos deviam seguir a religião do governante. Nesta conjuntura, no sul dos Países Baixos, nos avisa Freedberg, os católicos publicaram uma "avalanche" de livros e panfletos não só para reforçar a defesa do uso de imagens nos cultos, mas também como prescrição para que os fiéis não incorressem em erros idolátricos. Por outro lado, no que concerne à tensão ao redor das práticas letradas, os protestantes afirmavam que "onde o evangelho era aceito, e se crê nele, as imagens não são

11 EISENSTEIN, Elizabeth L. A revolução da cultura impressa. Os primórdios da Europa moderna. São Paulo: Ática, 1998, p.38.

12 BOUZA, Fernando. Imagen y propaganda. Capítulos de historia cultural del reinado de Felipe II. Madrid: Akal, 1998.

13 GRUZINSKI, Serge. A guerra das imagens. De Cristóvão Colombo a Blade Runner (1492-2019). São Paulo: Companhia das Letras, 2016, p. 57. 
necessárias". ${ }^{14}$ Nota-se que a tese de Elizabeth Eisenstein faz sentido quando destaca o papel da imprensa nas reformas religiosas. Alinhando a tese de Eisenstein com a de Freedberg, podemos ser ainda mais específicos, e afirmar que a querela das imagens estava no cerne da revolução impressa que se formou no movimento das reformas.

\section{Guerra com imagens, letras e performance}

As imagens sempre foram fonte de preocupação para o cristianismo, sobretudo as que tinham a forma de esculturas. A possível confusão entre imagens cristãs e imagens de cultos considerados pagãos provocaram enormes desconfianças entre os fiéis, assim como gestaram muitas questões para as autoridades religiosas resolverem nos primeiros séculos depois de Cristo. A tridimensionalidade das esculturas, por exemplo, era um problema - elas pareciam-se muito com o corpo humano, além de serem manipuláveis, algo considerado desonroso de acordo com a nascente cultura cristã. Os Pais da Igreja debruçaram-se sobre espinhosas questões teológicas na tentativa de definir o que era, ou não, "idolatria".

Em seu antigo sentido, de origem greco-romana, Eidôlon latreia significava "culto dos ídolos". No entanto, como nos lembra o historiador Alain Besançon, a palavra idolatria é somente encontrada no Novo Testamento. ${ }^{15}$ Havia repúdio por parte da Igreja aos eidôlon, então considerados simulacros. Outrossim, "ídolo" é relacionado, desde as origens cristãs, a uma divindade falsa. Em outras palavras: ídolo tornou-se algo apartado de um Deus considerado verdadeiro.

Muita tinta e muita oratória foram gastas para afastar as imagens cristãs, sobretudo os ícones, das suspeitas de induzirem a idolatria. Os fiéis cristãos, obviamente, não queriam ser considerados idólatras. Idólatra era o "outro". Como a filósofa Marie-José Mondzain salientou, "Idólatras eram os judeus, os gregos, e os bárbaros, idólatra era tudo que não era cristão". Marcou-se, assim, uma fronteira de alteridade que perdurou durante séculos. Segundo os estudos de Mondzain, a palavra de ordem entre os cristãos era: "É preciso quebrar os ídolos. Só com o desaparecimento material deles desapareceria a ameaça de sua ficção poderosa". ${ }^{16}$ Notase que os ídolos eram temidos por seus poderes, e somente o seu extermínio físico - a eliminação do corpo esculpido em pedra - traria algum conforto à comunidade cristã. Ainda de acordo com Mondzain: "A história dos ídolos nunca se passa sem o assassinato, e o ídolo não é, por definição, nem o dinamismo abstrato do signo nem a economia viva dos símbolos, mas a existência turbulenta e obsoleta dos corpos destrutíveis e sacrificados". ${ }^{17}$ No medievo, "aperfeiçoou-se" a

14 FREEDBERG, David. Iconoclasia. Historia y psicología de la violencia contra las imágenes. Sans Soleil Ediciones: Buenos Aires, 2017, p. 105.

15 BESANÇON, Alain. A imagem proibida. Uma história intelectual da iconoclastia. Rio de Janeiro: Bertrand, 1997, p. 109.

16 MONDZAIN, Marie-José. Imagem, ícone, economia. As fontes bizantinas do imaginário contemporâneo. Rio de Janeiro: Contraponto: Museu de Arte do Rio, 2013, p. 233.

17 Idem. 
performance de destruição dos "corpos pagãos", como se nota nesta correspondência de vinte de agosto de 1320, entre o papado e três inquisidores, dentre eles, Bernardo Gui:

[Era preciso agir] contra os que fazem pactos explícitos de obrigação com esses demônios, ou que fabricam ou fazem fabricar, qualquer imagem ou qualquer outra coisa com o objetivo de ligarem-se aos demônios ou para prepararem algum malefício por invocação dos demônios; contra aqueles que, abusando do sacramento do batismo, batizam ou fazem batizar uma imagem de cera ou de qualquer matéria, ou que, por outros meios e com invocação dos demônios, fabricam ou fazem fabricar essas imagens de alguma forma. ${ }^{18}$

Observa-se o medo que os religiosos tinham dos pactos demoníacos e invocações por meio de um sacramento católico às avessas. Ao se batizar uma imagem dava-se um nome. Ela ganhava vida.

Coube às autoridades católicas a separação das imagens sagradas daquelas consideradas pagãs. Jérôme Baschet, medievalista francês, ao abordar as funções das imagens na Idade Média, destacou os esforços de teólogos para justificar os seus usos nos cultos cristãos. Os homens da Igreja chegaram à formulação de uma tríade das funções imagéticas: instruir, rememorar e emocionar. Ainda conforme Baschet, entre os séculos XII e XIII foi desenvolvida a noção de transitus, sintetizada no pensamento de Hugo de Saint-Victor, para quem as imagens serviam para que os fiéis contemplassem as coisas invisíveis pela semelhança que guardam com as coisas visíveis. As imagens cristãs eram consideradas um meio para se aproximar de Deus e das coisas divinas. ${ }^{19}$ Por outro lado, as imagens usadas pelos idólatras, quando não eram consideradas pelos cristãos apenas como ilusão, eram o próprio corpo do deus pagão, daí o porquê de muitas receberem sacrifícios de mãos indígenas, na interpretação feita pelos padres. Nesse sentido, com toda a tradição europeia do conceito, os conquistadores no Novo Mundo viram nas manifestações indígenas as idolatrias a serem combatidas e extirpadas, e escreveram sobre esse embate.

Carmen Bernand e Serge Gruzinski, em sua arqueologia das ciências religiosas no período da expansão ibérica, demonstram como as redes de debates em torno da ideia de idolatria especialmente a rede lascasiana -, lançaram-se sobre a América e reduziram as religiosidades ameríndias a noções já conhecidas, advindas do paganismo antigo e da escolástica medieval. Las Casas retoma uma tradição segundo a qual o conhecimento de Deus é algo inerente ao homem, mas faz uma importante distinção entre a ideia de latria, veneração ao verdadeiro Deus, e idolatria, que ocorre quando o homem se perde na crença de falsos deuses. ${ }^{20}$

Em parte da América Hispânica, a ideia de idolatria para identificar as religiões Incas e Astecas se deu de forma mais clara pelos conquistadores, devido à presença de santuários

18 Carta em nome do Papa João XXII Apud. BOUREAU, Alain. Satã Herético. O nascimento da demonologia na Europa Medieval (1280-1330). Campinas: Editora da UNICAMP, 2016, p.31.

19 BASCHET, Jérôme. A civilização feudal. Do ano mil à colonização da América. Porto Alegre: Editora Globo, 2006, p. 485.

20 BERNAND, Carmen; GRUZINSKI, Serge, De la idolatria. Una arqueología de las ciencias religiosas, México: Fondo De Cultura Economica USA, 1992, p. 42. 
dedicados aos deuses, figuras de pedras representando estas deidades - especialmente no México - e uma estrutura ritual que estava relacionada aos centros de poder políticos. No entanto, nas regiões periféricas do Peru, no Caribe e na América Portuguesa, a ausência de ídolos de pedra levou alguns cronistas a constatarem a ausência de Fé ou de idolatria entre estes indígenas. No verbete Idolatria, do Vocabulário Português e Latino do lexicógrafo Raphael Bluteau, esta diferença aparece da seguinte forma:

A América, novo mundo ultimamente descoberto, estava cheia de idolatrias, principalmente nos Impérios do Peru e do México, e em todo o Brasil não havia nem Fé, nem Lei, nem Rei, só entre alguns destes bárbaros, atemorizados com o estrondo dos trovões e violência dos raios, havia opinião de uma Excelência superior, dominante, a que eles chamam Tupã, que em sua língua vai [sic] o mesmo que Excelência Espantosa. Mas finalmente com o zelo, e doutrina dos missionários portugueses, e castelhanos, se extirpou dos ditos impérios, e da Costa Meridional a idolatria. ${ }^{21}$

A ausência de ídolos, porém, não impediu missionários cristãos de enxergarem idolatria entre esses povos. De acordo com Bernand e Gruzinski, a rede lascasiana considera que o papel dos ministros e sacerdotes indígenas como mediadores da ação do demônio precede o dos ídolos. ${ }^{22} \mathrm{O}$ que se observa, portanto, é que mesmo na ausência dos temidos ídolos de pedra, o "olhar colonizador" identifica os rituais indígenas com as idolatrias conhecidas no Velho Mundo. Jean de Léry, descrevendo um dos ritos indígenas que presenciou, refere-se a ele como bacanal, evocando a imagem do paganismo clássico para explicar as "santidades" ameríndias. Há ainda nas descrições dos cronistas uma associação dos maracás indígenas à imagem de ídolos. Nas palavras do arcabuzeiro Hans Staden "[os maracás] são então os seus deuses". ${ }^{23}$ Nesse sentido, vale lembrar que entre os europeus no Novo Mundo, os sacrifícios realizados pelos ameríndios aos seus deuses foram interpretados como um grau máximo de alteridade, sobretudo, quando se tratou de um sacrifício humano diante de um ídolo.

O combate à idolatria, como um fenômeno religioso, político e social, ecoa entre a Idade Média e a Moderna. A Igreja colonial, dentre outros traços, possui o de certo medievalismo, destacado por Baschet, ao afirmar que:

O uso maciço das representações, a denúncia da idolatria, a proximidade entre imagens dos cristãos e as que eles denominam ídolos: tudo isso é destinado a reproduzir-se quase identicamente no Novo Mundo, onde a Conquista toma forma de uma "guerra das imagens". ${ }^{24}$

21 BLUTEAU, Rafael, Idolatria, in: Vocabulario Portuguez e latino: aulico, anatomico, architectonico..., Coimbra: Collegio das Artes da Companhia de Jesus, 1713, v. 4, p. 34.

22 BERNAND, GRUZINSKI. Op.cit. p. 70.

23 STADEN, Hans. Duas viagens ao Brasil. Trad. Guiomar de Carvalho Franco. Belo Horizonte/São Paulo: Itatiaia/Edusp, 1974, p. 174.

24 BASCHET, A civilização feudal... Op. cit. 
Tomamos aqui a liberdade para estender a conclusão de Baschet e afirmar que o mesmo ocorria em partes da África e da Ásia sob a colonização ibérica graças, sobretudo, à expansão dos impressos. Mais adiante, por meio de imagens, mostraremos essa estendida geografia do combate à idolatria. Acreditamos que isso não cause nenhuma surpresa a quem já entrou em contato com documentações das ações de ordens religiosas que encaravam suas missões em sentido universal, como a jesuítica, a franciscana, ou a dominicana. No entanto, chamamos aqui a atenção para a capacidade de se refletir sobre uma perspectiva global por meio das imagens, pois tais presenças de ordens religiosas em espaços fora da Europa são comumente estudadas apenas em perspectiva local, quando muito, para dois espaços coloniais em comparação. No período moderno, por conta da expansão europeia - diga-se cristã - Ásia, África e América conheceram as ações dos destruidores de ídolos.

A América hispânica possui uma diferença crucial em relação à portuguesa no âmbito da cultura escrita. Na América Portuguesa, sabemos que a instalação de prensas, por anteriores proibições governativas, ocorreu apenas no século XIX. No espaço hispânico, houve a instalação de prensas já no século XVI, acompanhando, assim, as demandas locais das universidades também criadas neste período. Portanto, não se pode estranhar que um dos principais problemas para os evangelizadores hispanos fosse tema constantemente abordado em livros publicados no México e em Lima quando a extirpação da idolatria estava em seu auge. Nesta última região, no ano de 1621, veio à luz uma obra com caráter prescritivo, mas que compilava, no formato in quarto, muitas experiências no combate às práticas consideradas idolátricas. Trata-se de Extirpacion de la idolatria del Piru, obra do padre jesuíta Pablo José de Arriaga, dividida em vinte capítulos somados a anexos. Seu primeiro capítulo trata da descoberta das chamadas idolatrias, e expõe o caráter "performático" próprio de uma sociedade barroca, em que a cultura visual era de suma significância:

Destes ídolos se fez um auto público na praça desta cidade de Lima, convocando para ele todos os índios de quatro léguas ao redor. Fazendo-se dois tablados com passadiço de um ao outro. O primeiro, um dique, e nele um monte de lenha onde iam passando os ídolos, e todos os seus ornamentos, e jogavam na lenha. Onde também estava amarrado a um bastão um índio chamado Hernando Paucar grande mestre da idolatria, e que falava com o demônio, natural de São Pedro de Mama, a quem todos os índios à sua volta tinham muita veneração. E depois de haver pregado a este ato o dito Doutor Ávila na língua geral dos índios, estando o Senhor Vice-rei inclinado à sua janela, de onde via e ouvia tudo, se publicou a sentença, e açoitaram ao dito índio, e se colocou fogo na lenha onde estavam os ídolos. ${ }^{25}$

25 "Destos Idolos se hizo un auto publico en la plaça desta ciudad de Lima, convocando para el todos los indios de quatro leguas al deredor. Hiziendose dos tablados com paladiço del uno al otro. El uno de terrapleno, y en el mucha leña donde ivan pasando los Idolos, y todos sus ornamentos, y arrojaban en la leña. Donde tambien estava amarrado a un palo un indio llamado Hernando Paucar grande maestro de la idolatria, y q hablava con el demonio, natural de S. Pedro de Mama, a quien em todos su contornos tenian los indios em mucha veneracion. Y despues de aver predicado a este acto el dicho Doctor Avila em la lengua general de los indios, estando o Señor Virrey asomado a su vetana, de donde se veya, y oya todo, se publico la sentencia, y açotaron al dicho indio, y se pegò fuego a la leña, donde estavan los ídolos". ARRIAGA, José. Extirpacion de la idolatria del Piru. Dirigido al Rey NS em seu Real Conseio de Indias. Por el 
Nas próprias memórias de Francisco de Ávila, ficamos a par do que se passou nesse auto de fé que ocorreu em Lima no dia 20 de dezembro de 1609. Ávila, trinta anos depois, se recorda de todo o dispositivo que objetivava garantir a maior visibilidade possível ao castigo imposto ao índio considerado "falso sacerdote", Hernando Paucar, que recebeu duzentos açoites em público, teve seu cabelo cortado, e foi desterrado para o Colégio jesuíta em Santiago do Chile. No auto, o poder temporal, representado pelo Cabido e o Vice-Rei, estava presente e, junto ao espiritual, realizou um cortejo até os tablados. A intenção era clara: "para que o vissem e assistissem, os índios de quatro léguas ao redor". ${ }^{26}$

\section{Corpos dos idólatras, corpos dos ídolos}

Por meio de gravuras e dos escritos coloniais, é possível perceber o imaginário europeu a respeito do que foi considerado como um "ídolo" entre os povos ameríndios. Sobre o papel das imagens europeias na demonização dos povos nativos há, pelo menos, dois estudos de referência na historiografia brasileira acerca da colonização do Novo Mundo. Em sua pesquisa, Ronald Raminelli faz menção aos modelos visuais europeus de seres demoníacos que serviram aos intentos representativos de navegadores, de conquistadores, de letrados, de religiosos e, claro, de artistas. Já o historiador Yobenj Aucardo Chicangana-Bayona, que defendeu sua tese de doutorado na Universidade Federal Fluminense, destaca a presença de modelos de corpos pagãos na constituição física dos indígenas: índias filhas de Saturno e Tupinambás apolíneos. ${ }^{27}$ Somase a isto, séculos de obras tratadísticas sobre a relação entre imagens, demônios e figuras pagãs da antiguidade clássica, e temos então uma cultura visual preparada para detectar vestígios de idolatria em terras recém-descobertas.

O que vemos, ao olharmos os ídolos nas gravuras que representam sua destruição, por vezes, são apenas os corpos dos ameríndios, colocados ali como estátuas em poses clássicas. No entanto, o mais comum é vermos o ídolo representado como resultante da junção do corpo indígena com os corpos de animais, criando um ser antropomorfo, parente próximo dos seres que habitam os capitéis e os códices medievais. Vê-se também seres com cabeças na barriga, com asas de morcego e serpentes fazendo as vezes de braços (Figuras 1 e 2). Enfim, há toda uma fauna fantástica oriunda de modelos ornamentais que estiveram muito em voga na arte maneirista, os famosos grotescos. Tais gravuras ilustravam diversos livros sobre o Novo Mundo.

padre Pablo Ioseph de Arriaga de la Compañia de Iesus. Lima: 1621, p. 3. Disponível em: <https://archive.org/details/extirpaciondelai00arri/page/2/mode/2up?view=theater\&q=Destos+Ido-

los+se+hizo+un+auto+publico >. Acesso em 28 de agosto de 2021. Tradução nossa.

26"para que lo viesen y asistiesen a ello, los indios de cuatro leguas alrededor". Idem, grifo nosso, tradução nossa.

27 Cf. RAMINELLI, Ronald. Imagens da colonização. A representação do Índio de Caminha a Vieira. Rio de Janeiro: Jorge Zahar, 1996. e CHICANGANA-BAYONA, Yobenj Aucardo. Imagens de canibais e selvagens do Novo Mundo. Do maravilhoso medieval ao exótico colonial (séculos XV-XVII). Campinas: Editora UNICAMP, 2017. 
Figura 1 - PLAUTIUS, Caspar. Nova typis transacta navigatio. Linz, 1621. Detalhe.

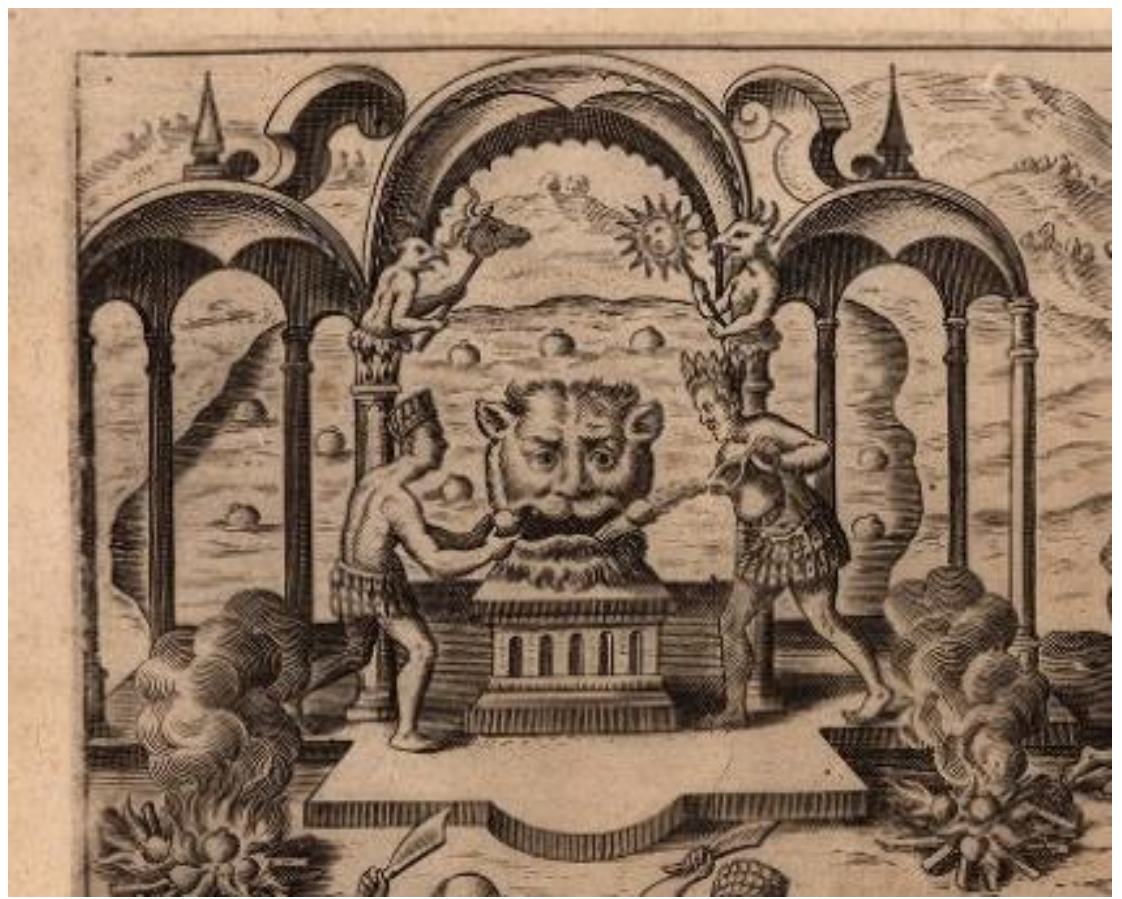

Fonte: Cortesia da Biblioteca John Carter Brown, da Brown University.

Figura 2 - FRANCISCI, Erasmus. Neu-polirter Geschicht-Kunst-und Sitten-Spiegel ausländischer Völcker, fürnemlich der Sineser, Japaner, Jndostaner, Javaner, Malabaren, Peguaner, Siammer, Peruaner, Mexicaner, Brasilianer. Nuremberg, 1670. Prancha 18.

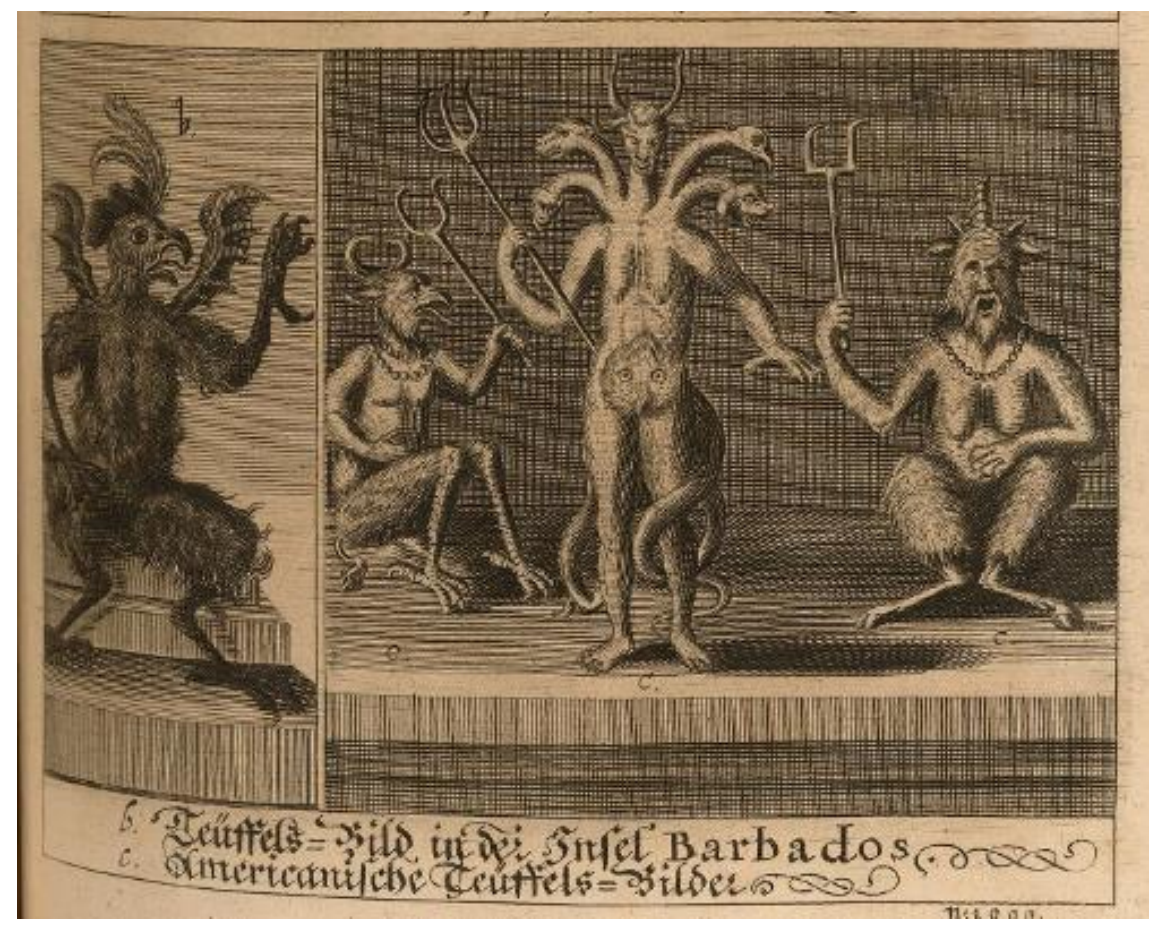

Fonte: Cortesia da Biblioteca John Carter Brown, da Brown University. 
Cabe aqui um adendo importante: ao explorarmos tal tema nos séculos XVI ao XVII, estamos lidando, sobretudo, com uma sociedade que idealizava o bom corpo político como algo harmonioso, em que as diferentes partes cumpriam uma função específica, se assemelhando, por analogia, ao corpo humano. A destruição do corpo de pedra do demônio indígena, um corpo considerado disforme, e sua posterior substituição pelo corpo católico europeu, tido como perfeito, possuía também o sentido, para os que viam as gravuras e liam os livros, de extirpação de um modelo de desgoverno.

Não somente os corpos indígenas estavam sob suspeita e sob controle político-religioso dos europeus no Novo Mundo. O historiador Jorge Canizares-Esguerra nos lembra que

os negros e mulatos eram em particular considerados potenciais aliados do diabo. O 2 de maio de 1612, por exemplo, trinta e cinco negros e mulatos, acusados de haver planejado um levantamento, foram enforcados na Cidade do México, e seus corpos foram esquartejados e decapitados. ${ }^{28}$

A justificativa das autoridades para a destruição dos corpos desses sujeitos foi a de que: "o levantamento que planejavam se considerava parte de uma estratégia mais ampla de Satã para gerar o caos". ${ }^{29}$ Como de costume, em uma pedagogia macabra, tais corpos mutilados foram expostos em diversos locais aos olhos de todos. Relatos das extirpações de idolatrias no Vice-Reino do Peru apontam ainda para a punição dos corpos de índios participantes de "seitas idolátricas". ${ }^{30}$ Do corte de cabelo - considerado uma terrível degradação por boa parte dos povos andinos - até o açoitamento público e a destruição, na ausência dos ídolos de pedra, dos ancestrais mumificados, foram diversos os tormentos infligidos aos corpos indígenas. Seja em forma de carne, de pedra ou de outros materiais, em um espetáculo que unia visualidade e poder político-religioso, os corpos dos considerados "outros" foram supliciados e exibidos.

Na Europa, sobretudo entre os anos de 1525 e 1585, uma profusão de modelos iconográficos representando as derrubadas de ídolos saíram de prensas católicas e protestantes. 0 discurso era um tanto ambíguo, a depender da posição dos gravadores e dos tipógrafos (alguns trabalhavam para os dois lados em disputa, e reutilizavam as matrizes de metal). Destacaramse temáticas bíblicas como "Bel e o dragão", gravado por Hieronymus Cock, em 1564; "A destruição do templo de Ball", por Maarten Van Heemskerck, em 1567; e a "História de Josias", por Galle, em 1569. ${ }^{31}$ Nestas imagens, observa-se que a performance dos corpos que destroem os

28 "los negros y mulatos eran en particular considerados potenciales aliados del diablo. El 2 de mayo de 1612, por ejemplo, treinta e cinco negros y mulatos, acusados de haber planeado un levantamiento, fueron ahorcados en la Ciudad de México, y sus cuerpos fueron descuartizados o decapitados". CAÑIZARES-ESGUERRA, Jorge. Católicos y puritanos en la colonización de América. Madrid: Marcial Pons, 2008, p. 48, tradução nossa.

29 "el levantamiento que planeaban se consideraba parte de una estrategia más amplia de Satán para generar ao caos". Op. Cit., tradução nossa.

30 ALBORNOZ, Cristóbal. Informaciones de servicios [1569, 1570, 1577 e 1584]. In: MILLONES, Luis (Ed.). El Retorno de las Huacas. Estudios y Documentos del Siglo XVI. 1. ed. Lima: Instituto de Estudios Peruanos y Sociedad Peruana de Psicoanálisis, 1990, p. 260.

31 FREEDBERG, Iconoclasia, p.157. 
ídolos das histórias bíblicas assemelha-se a que operará os corpos dos conquistadores que destruirão os chamados ídolos nativos do Novo Mundo contando, inclusive, com o assassinato dos sacerdotes, e posterior exibição de seus corpos nos templos considerados pagãos.

\section{Ódio pelos ídolos, ódio pelo "outro"}

Embora as estratégias de conversão católica mudassem e se adaptassem às contingências locais, a destruição dos ídolos era uma constante por parte dos colonizadores. Outro aspecto visto nas áreas colonizadas: não bastava aos europeus simplesmente destruir as representações das divindades nativas. Era preciso registrar a performance da destruição, e desta forma divulgar que o terreno estava pronto para o avanço colonizador/civilizador. Se para o reino do Congo há a imagem de um capuchinho italiano incendiando uma casa onde se realizavam rituais para "ídolos"; para o México um dos registros coloniais exibe frades franciscanos espanhóis ateando fogo em códices astecas. No fólio $242 r$ da Discripción de la Ciudad y Provincia de Tlaxcala, as imagens astecas queimadas estão representadas como se estivessem flutuando (Fig.3). Os registros astecas são representados como se fossem uma aparição sendo enfrentada por dois religiosos tonsurados com tochas nas mãos. O manuscrito de Diego Muñoz Camargo (15291599) está sob os cuidados da Universidade de Glascow. Ele é uma realização de indígenas que, na segunda metade do século XVI, registraram visualmente as alianças entre as lideranças tlaxcaltecas e os conquistadores espanhóis.

Figura 3 - Descrição da cidade e província de Tlaxcala. Folio 242r.

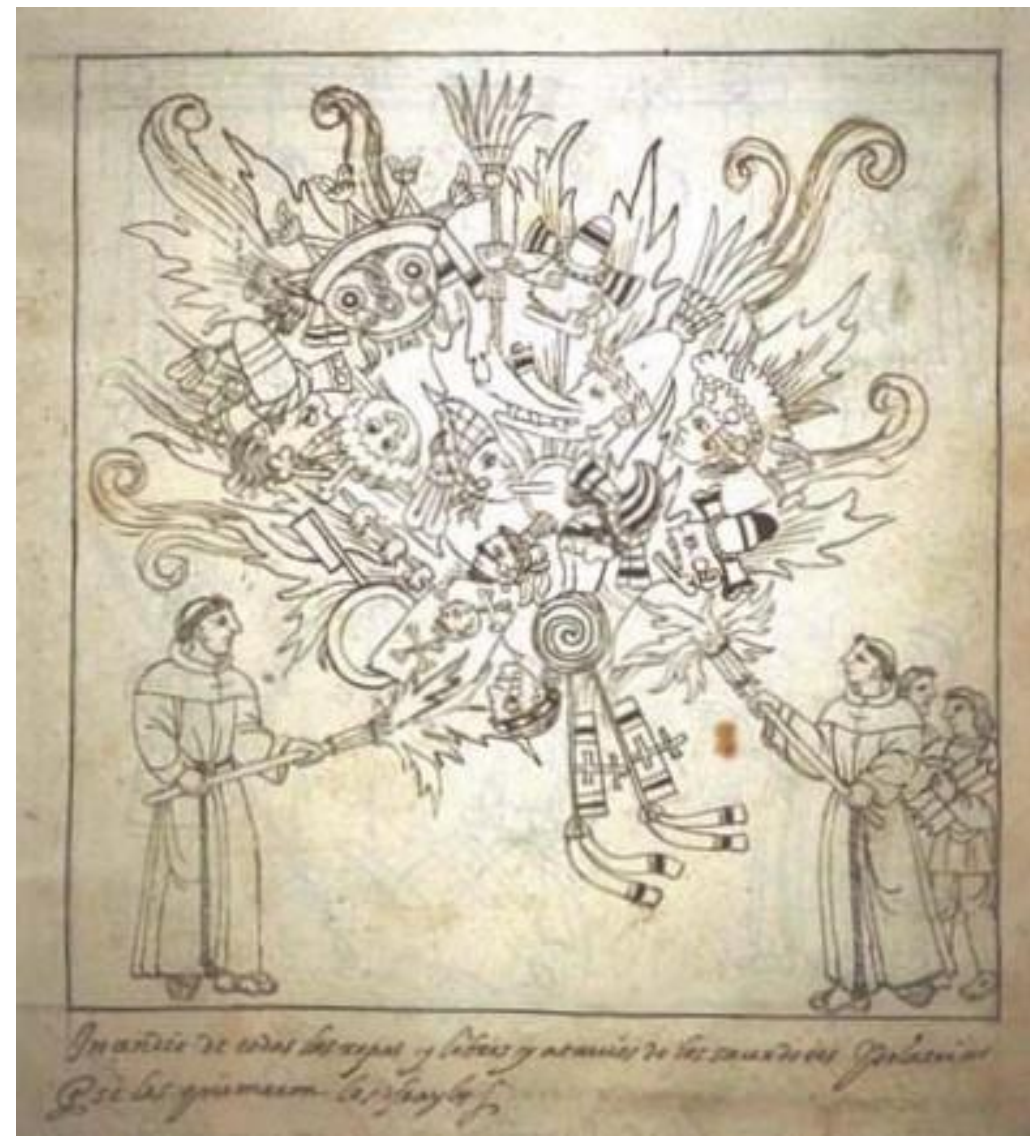

Fonte: Glasgow University Library, 2003. 
O próprio Muñoz de Camargo era mestiço, assim como o documento que apresenta titulis em castelhano. Essas imagens, que representam os tipos humanos em perfil, eram pinturas para um edifício do Cabildo de Tlaxcala, portanto, em suas origens, eram exibidas publicamente. Abaixo da imagem do fólio $242 r$, que é enquadrada por uma borda, há uma inscrição em casteIhano impondo um sentido para quem a vê, nela lê-se: "Incêndio de todas as roupas e livros e atavios dos sacerdotes idolátricos que thes queimaram os frades". ${ }^{32} \mathrm{O}$ alvo das chamas eram todos os aparatos para o culto considerado idolátrico, inclusive vestes sacerdotais, máscaras, imagens de ídolos e códices. Atrás de um dos freis, dois indígenas carregam mais rolos de códices.

Acreditava-se que as chamas possuíam poder de exorcizar objetos e figuras, como lembra um manual de exorcismo italiano que circulou muito por toda a Europa no século XVII, e que vinculava fórmulas usadas muitos séculos antes de sua publicação. Ele aconselhava a se desenhar demônios e sinais de feitiço em papéis para depois lançá-los ao fogo. A obra também sugeria que "pode lançar no chão por desprezo os retratos dos demônios, cuspir-lhes, e pôr-lhes os pés em cima". Tratava-se da prática exorcista chamada "benção do fogo, em que hão de queimar os papeis e figuras do demônio", e também "os sinaes dos feitiços, se aparecerem". ${ }^{33}$ Nota-se o quanto a destruição de imagens e de papéis estava no âmago da prática do exorcismo.

Em uma imagem que representa a região do Caribe, mais precisamente o Haiti, vê-se a performance da destruição dos ídolos com quase todos os elementos do teatro da colonização. Destacamos aqui as gravuras que compõem a obra Nova typis transacta navigatio (1621). Comumente, as gravuras desta obra seiscentista são apresentadas separadas em pesquisas que tratam da colonização das Américas, ou mesmo nas que versam sobre a presença de santos medievais no Atlântico. No entanto, a análise de uma única imagem ou um par delas é insuficiente para o entendimento da narrativa geral. As gravuras deste livro, publicado em Linz no ano de 1621, compõem a típica narrativa da colonização. Escrito por Caspar Plautius, um monge beneditino de Munique, o livro faz um elogio a Bernard Boyl, monge de Montserrat que acompanhou Cristóvão Colombo em sua segunda viagem, em 1493. O frontispício deste livro e as outras vinte e uma ilustrações são obras do gravador Wolfgang Killian (1581-1663), de Augsburgo. Elas possuem aspectos que fazem parte do olhar da catequese, um olhar colonizador, que vai desde a chegada das naus até ao final triunfante da Igreja sob os povos nativos (última gravura do livro).

A gravura que aqui destacamos, provavelmente relacionada a gravuras mais antigas de Theodore de Bry, mostra o desembarque de soldados espanhóis em uma baía (Figura 4). Eles

32 "Incendio de todas las ropas y libros y atavios de los sacerdotes idolatricos que se los quemaron los frades". Tradução nossa.

33 A edição em latim é de 1651. Aqui citamos a edição portuguesa de 1753, compilada por frei José de Jesus Maria: Brognolo recopilado, e substanciado com additamentos de gravissimos authores: methodo mais breve, mui suave, e utilissimo de exorcizar... Lisboa: Officina de Miguel Menescal da Costa, 1753, p. 284. Biblioteca Nacional (RJ), Acervo de Obras Raras: V - 419-1-2. 
lutam ao lado de indígenas aliados dos europeus contra nativos que resistiam à colonização. No centro dessa cena, vemos um religioso derrubando um ídolo de seu pedestal, enquanto seus companheiros de hábito jazem com flechadas e pancadas de tacapes. Geralmente esses religiosos, mortos nas missionações além-mar, foram recordados por seus pares como mártires, e alguns até alcançaram a santificação. Tudo parece ecoar o que disse, quase um século antes, o cronista Francisco López de Gómara em Historia General de las Indias y conquista de México (1552), clérigo próximo de Cortés, mas que nunca pisou no Novo Mundo: "Na verdade, [o objetivo] da guerra e da gente de armas é retirar desses índios os seus ídolos" ${ }^{\prime 34}$. No céu, ao fundo da imagem, a aparição da Virgem e do menino Jesus surge jogando raios de luz sobre os combatentes espanhóis, no que é uma clara referência à ajuda divina que os europeus católicos acreditavam receber.

Figura 4 - PLAUTIUS, Caspar. Nova typis transacta navigatio. Linz, 1621. p. 44.

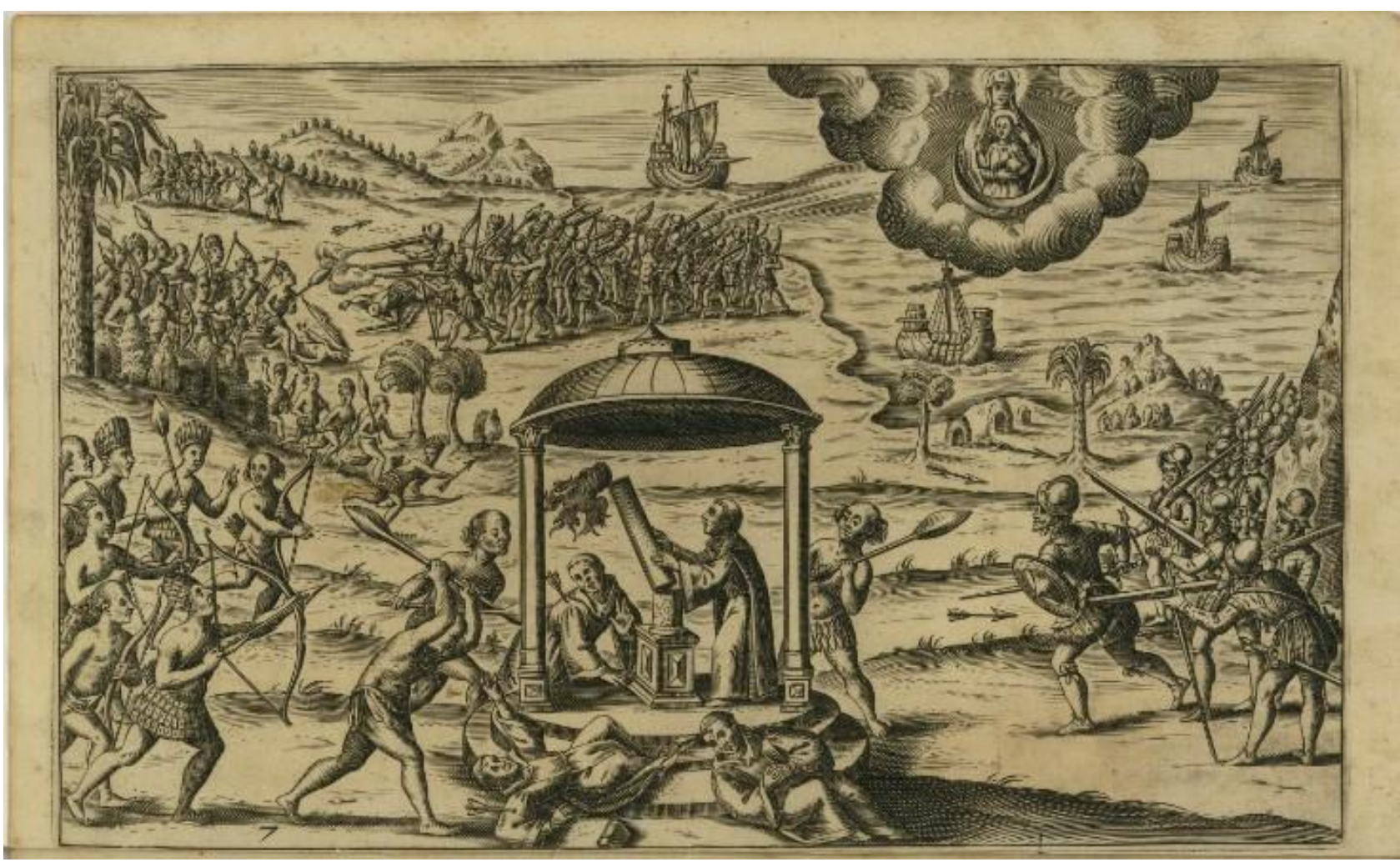

Fonte: Cortesia da Biblioteca John Carter Brown, da Brown University.

Vale lembrar a figura de São Tiago, santo católico que quase sempre era representado em batalhas coloniais. Este santo, que na Europa era conhecido como Santiago Matamouros, na América ficou conhecido como Santiago Mata-índios. No fólio 404 da Nueva Corónica y Buen

34 "Y ala verdad la guerra, y la gente con armas es para quitar a estos indios los ídolos". GÓMARA, Francisco López de. La historia general de las Indias, y todo lo acaescido en ellas dende que se ganaron hasta agora y La conquista de Mexico, y dela Nueua España. Anvers: Martin Lucio, 1554, p. 21. Disponível em: <https://archive.org/details/lahistoriagenera00lpez_0/page/n45/mode/2up?q=guerra>. Acesso em 28 de agosto de 2021, tradução nossa. 
Gobierno, de Felipe Guamán Poma de Ayala, há uma gravura de São Tiago montado em seu cavalo sobre um indígena que se encontra caído no chão (Figura 5). Na mão direita, o cavaleiro empunha sua espada e na esquerda carrega o estandarte em forma de cruz. No peito traz também uma cruz, símbolo da Ordem de Cavalaria de Santiago. Essa representação do santo cruzadista, comum no período da Reconquista Ibérica, atravessou o Atlântico e foi apropriada para a conquista da América. É interessante observar que, nesse caso, a figura de Santiago Mataíndios foi apropriada justamente por um cronista indígena convertido ao catolicismo e agora súdito da Coroa de Castela. Na gravura, observa-se ainda a inscrição "Conquista / milagre do Santo São Tiago Maior, apóstolo de Jesus Cristo / em Cusco". ${ }^{35} \mathrm{O}$ texto que segue narra como os nativos infiéis que compunham a tropa de Manco Inca no cerco de Cusco testemunharam os milagres do santo, que desceu com um trovão sobre a terra para garantir a vitória dos espanhóis contra os indígenas.

35 "Conquista / milagro del Santo Santiago Mayor, apóstol de Jesucristo / en el Cuzco". GUAMAN POMA DE AYALA, Felipe. Nueva Corónica y Buen Gobierno., v. 1, Ayacucho: Fundación Biblioteca Ayacucho, 1980, p. 29, tradução nossa. 
Figura 5

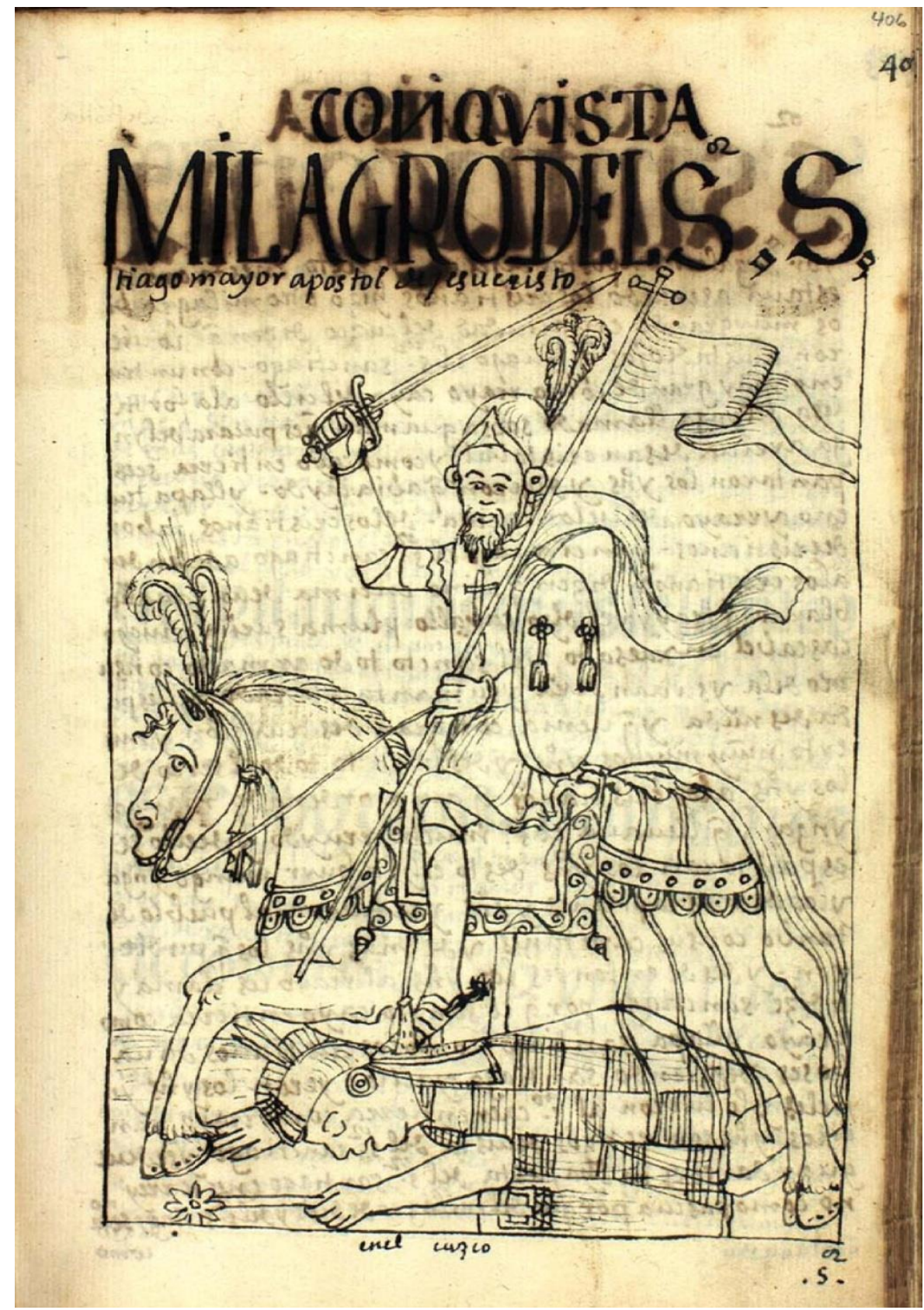

Fonte: GUAMAN POMA DE AYALA, Felipe. Nueva Corónica y Buen Gobierno., v. 1, Ayacucho: Fundación Biblioteca Ayacucho, 1980, f.404.

Voltando à gravura da Nova typis transacta navigatio, chama a atenção o fato do templo e do ídolo serem representações de um modelo arquitetônico europeu, ou seja, uma simples transposição de antigas divindades pagãs europeias para as terras do Novo Mundo. Sabemos, por meio de registros arqueológicos e outras fontes históricas, que os rituais ameríndios não eram realizados em templos como o exposto na gravura. Sobre o assunto, Gruzinski destaca 
que os ídolos habitavam "a escuridão dos santuários, longe da multidão, e da visibilidade". ${ }^{36}$ Portanto, os ídolos ameríndios ficavam escondidos dos olhos de todos. Na gravura em questão, a cena se desenrola ao ar livre, em um litoral, possibilitando a visualização de toda a narrativa da conquista. Pequenas ocas perto da praia sugerem que se trata de um grupo indígena habitante do litoral. A estratégia visual aqui empreendida, mostrando espanhóis mortos em combate, tenta dar conta de uma valoração comum às lógicas imperiais ibéricas, quando conquistadores escreviam ao rei informando que a custa de seus homens e cabedais empreendiam o avanço por terra.

Um ponto interessante a ser observado quando tratamos da destruição de ídolos no Novo Mundo é a ausência de imagens que representem a extirpação idolátrica no Vice-reino do Peru. Embora os povos andinos tenham sido tratados pelos europeus como idólatras, especialmente em comparação com os índios do Brasil, sua relação com o sagrado dificultou sobremaneira a extirpação de idolatrias, principalmente nas regiões periféricas do Império Inca onde os cultos do Sol (Inti) e de Viracocha - divindades que possuíam representação imagética - eram menos comuns. De modo geral, as divindades andinas eram elementos da própria paisagem no entorno. O próprio termo quíchua huaca, que pode ser entendido como deus/deusa, tem uma série de significados. De acordo com Garcilaso de la Vega, huaca pode significar "ídolo" ou "coisa sagrada", como rochas, pedras grandes e árvores. Pode significar ainda oferendas feitas aos deuses e qualquer local considerado sagrado. Os indígenas também chamavam huaca a todas as coisas que se diferenciavam das comuns, seja por serem muito belas ou monstruosas, ou ainda por "saírem do curso natural", como o nascimento de gêmeos, seja de humanos ou de animais. Garcilaso de la Vega defende ainda que tais definições são significativas do erro dos cronistas espanhóis ao tentarem compreender os indígenas, visto que tomaram por deuses a tudo mais que era chamado de huaca, apreendendo apenas o sentido principal da palavra. ${ }^{37}$

Um dos exemplos mais concretos para compreendermos a questão acima são as chamadas huacas de caminho, montículos artificiais formados pelos indígenas ao longo dos anos. Tais estruturas, que marcam até hoje o cenário andino, são formadas por rochas e outros materiais, depositados paulatinamente pelos viajantes em locais específicos das estradas. Gonzalo Pimentel, arqueólogo especialista no estudo das chamadas huacas de caminho da região do Atacama, explica que os caminhos eram entendidos pelos viajantes como entidades vivas e que era fundamental o diálogo com essas entidades para que as viagens pudessem prosseguir de forma segura. Essa concepção se dá, de acordo com Pimentel, porque as sociedades andinas podem ser consideradas como metonímicas ou animistas, cujo eixo principal de ordenação da realidade se dá pelos elementos físicos do espaço. ${ }^{38}$ Assim, para os indígenas que precisavam passar pelas

36 GRUZINSKI, A guerra das imagens. Op. cit., p. 62.

37 DE LA VEGA, Inca Garcilaso. Comentarios Reales de los Incas. Arequipa: Ediciones El Lector SRL, 2014, p. 113-115.

38 PIMENTEL G, Gonzalo, Las huacas del tráfico. Arquitectura ceremonial en rutas prehispánicas del Desierto de Atacama, Boletín del Museo Chileno de Arte Precolombino, v.14, n. 2, p. 9-38, 2009. 
estradas andinas - fosse para trocar mercadorias ou para cumprir turnos de trabalho (mita) em localidades distantes de suas províncias de origem - o próprio caminho era considerado sagrado e capaz de intervir na sorte da viagem, por isso a necessidade de lhe fazer oferendas e prestar culto. Ao instruir os missionários católicos para destruírem as huacas, o visitador Cristóbal de Albornoz alerta para a dificuldade de retirar a "superstição" dos índios do Peru quanto às huacas de estrada "porque para tirar ditas huacas é necessário muita força que toda a gente do Peru não é suficiente [para] mudar estas pedras e montanhas". ${ }^{39}$

Nota-se que, mesmo com a impossibilidade de concretizar a performance da extirpação conforme ocorrida no México, por exemplo, o discurso produzido sobre os povos ameríndios seguia a lógica da "idoloclastia". Na ausência dos ídolos de pedra, o esforço deveria ser voltado tanto para a punição dos corpos indígenas quanto para a destruição dos próprios santuários e de seus sacerdotes, embora, em muitos casos, isso significasse atentar contra a própria geografia local.

\section{Considerações finais}

Ao final do século XVII, precisamente entre os anos de 1684 e 1695, o artista e tratadista Andrea Pozzo (1642-1709) realizou a pintura da abóbada da igreja jesuítica de Santo Inácio, em Roma, uma igreja no centro da cristandade, dedicada ao fundador da Ordem, ou seja, a mais importante de toda esta poderosa ordem religiosa. Tal espaço ganhou uma magnífica pintura perspectivada que serviu de modelo até para igrejas além-mar. Na obra deste pintor - que também viveu em Viena no começo do século XVIII - vê-se, dentre alegorias das partes do mundo em cada canto, uma da América representada por uma índia de cocar colorido, com o seio à mostra, enfrentando demônios com uma lança na mão. Ao seu lado está um papagaio (Figura 6). É sobretudo a expectativa de uma ordem que missionava em todas as partes: a de que nativos abandonassem os seus antigos ídolos e seus costumes e ajudassem a Igreja no combate ao demônio. Como colonização e conversão andavam de braços dados, podemos vê-la também como uma alegoria da ação de se colonizar as terras distantes das metrópoles. Portanto, trata-se de uma alegoria da colonização de corpos, almas e territórios. Lembremo-nos de que o índio catequizado tornava-se súdito de um governante europeu, logo, um pagador de tributos. Da destruição de ídolos no Novo Mundo ao teto de uma igreja desta envergadura, vê-se o quanto a ideia de um exorcismo do território fez parte dos projetos expansionistas colonizadores, e foi ação divulgada pelos impressores e gravadores.

39 ALBORNOZ, Cristóbal. Instrucción para descubrir todas las guacas del Piru. In: DUVIOLS, Pierre (Ed.). Un inédit de Cristóbal de Albornoz: La Instrucción para descubrir todas las guacas del Piru [sic] y sus camayos y hazienda. 1. ed. Paris: Journal de la Societé des Américanistes, 1967, v. 56. Disponível em: <https://www.persee.fr/doc/jsa_0037-9174_1967_num_56_1_2269>. Acesso em: 1 abr. 2020, p. 20. 
Figura 5 - Alegoria da América. Andrea Pozzo. Detalhe do teto da Igreja de Santo Inácio. Roma, Séc. XVII.

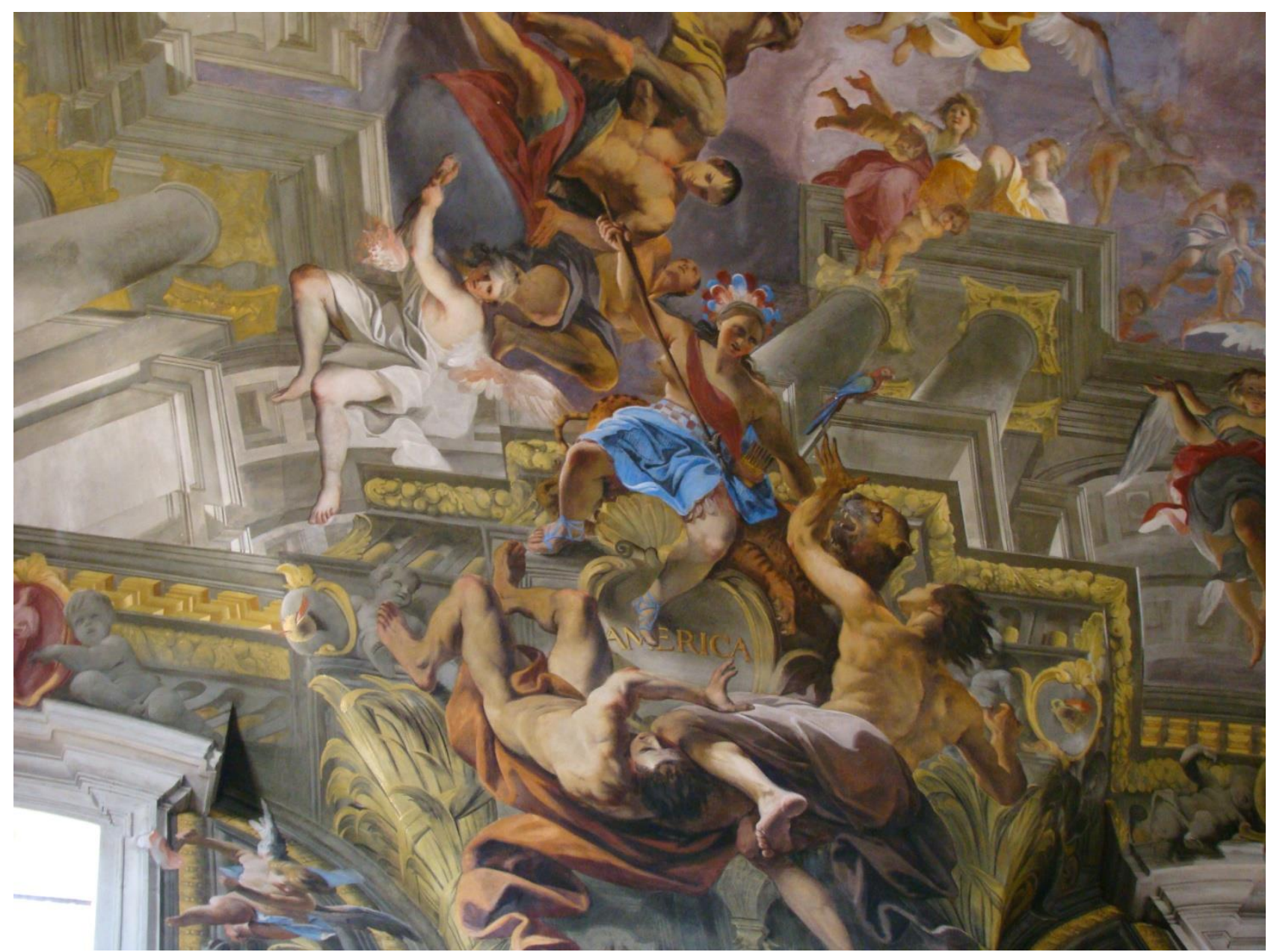

Fonte: Foto do autor.

Retomando as ideias de Luciana Villas-Bôas, citada no princípio deste artigo, podemos afirmar a importância dos impressos na constituição das identidades europeias, sobretudo, as de cunho político-religiosas. Ao propagandear, por meio de livros e de gravuras, a dizimação de imagens consideradas idolátricas no Novo Mundo, católicos forjavam certa resposta à "guerra de imagens" que enfrentavam em solo europeu contra protestantes. Em outras palavras, a Monarquia católica salientou iconograficamente que não tolerava os idólatras, assumindo assim, que as suas relações com as imagens tinham lógicas diversas das praticadas pelos ameríndios. Idólatra era sempre o "outro". 


\section{Referências}

ALBORNOZ, Cristóbal. Informaciones de servicios [1569, 1570, 1577 e 1584]. In: MILLONES, Luis (Ed.). El Retorno de las Huacas. Estudios y Documentos del Siglo XVI. 1. ed. Lima: Instituto de Estudios Peruanos y Sociedad Peruana de Psicoanálisis, 1990.

ALBORNOZ, Cristóbal. Instrucción para descubrir todas las guacas del Piru. In: DUVIOLS, Pierre (Ed.). Un inédit de Cristóbal de Albornoz: La Instrucción para descubrir todas las guacas del Piru [sic] y sus camayos y hazienda. 1. ed. Paris: Journal de la Societé des Américanistes, 1967, v. 56. Disponível em: <https://www.persee.fr/doc/jsa_0037-9174_1967_num_56_1_2269>. Acesso em: 1 abr. 2020.

ARRIAGA, José. Extirpacion de la idolatria del Piru. Dirigido al Rey NS em seu Real Conseio de Indias. Por el padre Pablo Ioseph de Arriaga de la Compañia de Iesus. Lima: 1621, p. 3. Disponível em: <https://archive.org/details/extirpaciondelai00arri/page/2/mode/2up?view=theater\&q=Destos+Idolos+se+hizo+un+auto+publico. > Acesso em 28 de agosto de 2021.

BASCHET, Jérôme. A civilização feudal. Do ano mil à colonização da América. Porto Alegre: Editora Globo, 2006.

BERNAND, Carmen; GRUZINSKI, Serge, De la idolatria. Una arqueología de las ciencias religiosas, México: Fondo De Cultura Economica USA, 1992.

BESANÇON, Alain. A imagem proibida. Uma história intelectual da iconoclastia. Rio de Janeiro: Bertrand, 1997.

BLUTEAU, Rafael, Idolatria, in: Vocabulario Portuguez e latino: aulico, anatomico, architectonico..., Coimbra: Collegio das Artes da Companhia de Jesu, 1713, v. 4.

BOUREAU, Alain. Satã Herético. O nascimento da demonologia na Europa Medieval (1280-1330). Campinas: Editora da UNICAMP, 2016.

BOUZA, Fernando. Imagen y propaganda. Capítulos de historia cultural del reinado de Felipe II. Madrid: Akal, 1998.

CAÑIZARES-ESGUERRA, Jorge. Católicos y puritanos en la colonización de América. Madrid: Marcial Pons, 2008.

CHICANGANA-BAYONA, Yobenj Aucardo. Imagens de canibais e selvagens do Novo Mundo. Do maravilhoso medieval ao exótico colonial (séculos XV-XVII). Campinas: Editora UNICAMP, 2017.

DE LA VEGA, Inca Garcilaso. Comentarios Reales de los Incas. Arequipa: Ediciones El Lector SRL, 2014.

DIDI-HUBERMAN, Georges. A imagem sobrevivente. história da arte e tempo dos fantasmas segundo Aby Warburg. Rio de Janeiro: Contraponto, 2013. 
EISENSTEIN, Elizabeth L. A revolução da cultura impressa. Os primórdios da Europa moderna. São Paulo: Ática, 1998.

FREEDBERG, David. Iconoclasia. Historia y psicología de la violencia contra las imágenes. Sans Soleil Ediciones: Buenos Aires, 2017. p. 101 e 105.

GELL, Alfred. Arte e agência. Uma teoria antropológica. São Paulo: UBU editora, 2018. GERBI, Antonello. O Novo Mundo. História de uma polêmica (1750-1900). São Paulo: Companhia das Letras, 1996.

GÓMARA, Francisco López de. La historia general de las Indias, y todo lo acaescido en ellas dende que se ganaron hasta agora y La conquista de Mexico, y dela Nueua España. Anvers: Martin Lucio, 1554, p. 21. Disponível em: <https://archive.org/details/lahistoriagenera00lpez_0/page/n45/mode/2up?q=guerra>. Acesso em 28 de agosto de 2021.

GREENBLATT, Stephen. Possessões maravilhosas. O des/umbramento do Novo Mundo. São Paulo: EDUSP, 1996.

GRUZINSKI, Serge. A guerra das imagens. De Cristóvão Colombo a Blade Runner (1492-2019). São Paulo: Companhia das Letras, 2016.

GUAMAN POMA DE AYALA, Felipe. Nueva Corónica y Buen Gobierno., v. 1, Ayacucho: Fundación Biblioteca Ayacucho, 1980.

JCB Archive of Early American Images. Disponível em: <https://jcb.lunaimaging.com/luna/servlet/JCB 1 1>. Acesso em 30 de agosto de 2020.

KNAUSS, Paulo. Aproximações disciplinares: História, Arte e Imagem. Anos 90, Porto Alegre, v. 15, n. 28, p.151-168, dez. 2008.

MARIA, José Jesus de (Comp.) Brognolo recopilado, e substanciado com additamentos de gravissimos authores: methodo mais breve, mui suave, e utilissimo de exorcizar... Lisboa: Officina de Miguel Menescal da Costa, 1753, p. 284. Bibioteca Nacional (RJ), Acervo de Obras Raras: V - 419-1-2.

MELLO E SOUZA, Marina de. Além do visível. Poder, catolicismo e comércio no Congo e em Angola (séculos XVI e XVII). São Paulo: EDUSP, FAPESP, 2018.

MITCHELL, W.T.J. Picture Theory. Chicago: Chicago Press, 1994.

MITCHELL, W.T.J. O que as imagens querem? In: ALLOA, Emmanuel (Org.). Pensar a imagem. Belo Horizonte: Autêntica, 2015. p. 165-189.

MONDZAIN, Marie-José. Imagem, ícone, economia. As fontes bizantinas do imaginário contemporâneo. Rio de Janeiro: Contraponto: Museu de Arte do Rio, 2013.

PHILOPONO, D. Honorio. Nova typis transacta navigatio: Novi Orbis Indiæ Occidentalis admodum reverendissimorum PP. ... Dn. Buellii Cataloni abbatis montis Serrati, \& in vniversam Americam, sive Novum Orbem sacræ sedis Apostolicæ Romanæ â latere legati, vicarij, ac patriarchæ: sociorumq[ue] monarchorum ex Ordine S.P.N. Benedicti ad suprà dicti Novi Mundi barbaras gentes Christi S. Evangelium prædicandi gratia delegatorum sacerdotum dimissi per S.D.D. Papam Alexandrum VI. Anno Christi 1492 : nunc primum e varijs scriptoribus in vnum collecta, 
\& figuris ornata / authore venerando Fr. Don Honorio Philopono Ordinis S. Benedicti Monacho. Munich, 1621. Disponível em: <http://www.bibliotecadigital.unicamp.br/document $/$ ?code $=000425794 \&$ opt $=1>$. Acesso em 30 de agosto de 2020 .

PIMENTEL G, Gonzalo, Las huacas del tráfico. Arquitectura ceremonial en rutas prehispánicas del Desierto de Atacama, Boletín del Museo Chileno de Arte Precolombino, v.14, n. 2, p. 9-38, 2009.

PRATT, Mary Louise. Os olhos do Império. Relatos de viagem e transculturação. São Paulo: EDUSC, 1999.

RAMINELLI, Ronald. Imagens da colonização. A representação do Índio de Caminha a Vieira. Rio de Janeiro: Jorge Zahar, 1996.

STADEN, Hans. Duas viagens ao Brasil. Trad. Guiomar de Carvalho Franco. Belo Horizonte/São Paulo: Itatiaia/Edusp, 1974.

VILLAS BÔAS, Luciana. Encontros escritos: semântica histórica do Brasil no século XVI. Rio de Janeiro: Editora da UFRJ, 2019, p. 20.

WARBURG, Aby. Histórias de fantasma para gente grande. Escritos, esboços e conferências. São Paulo: Companhia das Letras, 2015.

WOLF, Eric R. A Europa e os povos sem história. São Paulo: EDUSP, 2005.

XAVIER, Ângela Barreto. A invenção de Goa. Poder imperial e conversões culturais nos séculos XVI e XVII. Lisboa: Imprensa de Ciências Sociais, 2008. 